Kapata Arkeologi, 13(2), 233-246

ISSN (cetak): 1858-4101

ISSN (elektronik): 2503-0876

http://kapata-arkeologi.kemdikbud.go.id

\title{
SENI HIAS TEMPEL KERAMIK KESULTANAN CIREBON: TOLERANSI DALAM KEBINEKAAN
}

\section{Ornamental Art of Ceramic Tiles in Cirebon Sultanate: Tolerance in Diversity}

\author{
Naniek Harkantiningsih \\ Pusat Penelitian Arkeologi Nasional - Indonesia \\ Jl. Raya Condet Pejaten No. 4, Jakarta Selatan 12510 \\ naniek_hw@yahoo.com
}

Naskah diterima: 26/09/2017; direvisi: 04/11—18/11/2017; disetujui: 18/11/2017

Publikasi elektronik: 30/11/2017

\begin{abstract}
The Sultanate of Cirebon is the center of the Islamic empire that grew from the 15th century, in fact not only grew in the religious, bureaucratic, and commercial sphere, but also established cooperation with the Dutch, especially in the early 18th century, even become to region of the territory of VOC until the Dutch East Indies government. One of the proofs of the relationship, is the form of ceramic tiles from the Netherlands which until now used as decoration wall of the palace, mosque, and tombs. The pattern of ceramic tiles is biblical story. The existence of ceramic tiles of the biblical story in Cirebon as an area of the Islamic empire that was very influential at that time, certainly be uniqueness. Therefore, the purpose of this papers is to know the reasons for the preservation of the ornamental art of ceramic outboard bible stories in the center of government and sacred buildings characterized by Islam. The method used is qualitative analysis, context analysis, and literature study. The preservation of this ornamental art may also be linked to the tolerance of diversity, which is the current government policy program. The use of ceramic outboard art of Biblical story, both in profane and sacred building makes one of the typical culture of Cirebon, because the people of Cirebon and the Sultanate relatives still maintain the unity and preserve the cultural heritage.
\end{abstract}

Keywords: decorative art, ceramic tiles, Bible stories, Cirebon

\begin{abstract}
Abstrak
Kesultanan Cirebon sebagai pusat kerajaan Islam yang berkembang dari abad ke-15an, pada kenyataannya tidak hanya tumbuh dalam lingkup keagamaan, birokrasi, dan perniagaan, tetapi juga menjalin kerjasama dengan Belanda. Terutama pada awal abad ke-18an, bahkan menjadi wilayah kekuasaan VOC hingga pemerintahan Hindia Belanda. Salah satu bukti hubungan itu, berupa tegel keramik asal Belanda yang hingga kini dipakai sebagai hiasan tembok keraton, masjid, dan makam. Tegel keramik tersebut bermotifkan cerita Alkitab. Keberadaan tegel keramik cerita Alkitab di Cirebon sebagai wilayah kerajaan Islam yang sangat berpengaruh pada masa itu, tentu menjadi keunikan. Tujuan penulisan ini yaitu, mengetahui alasan pelestarian seni hias tempel keramik cerita Alkitab di pusat pemerintahan dan bangunan sakral bercirikan Islam. Metode yang digunakan ialah analisis kualitatif, analisis konteks, dan studi kepustakaan. Pelestarian seni hias ini mungkin dapat pula dihubungkan dengan toleransi kebinekaan, yang menjadi program kebijakan pemerintah saat ini. Penggunaan seni hias tempel keramik cerita Alkitab, baik di bangunan profan maupun sakral menjadikan salah satu budaya khas Cirebon, karena masyarakat Cirebon dan kerabat Kesultanan masih menjaga keutuhan dan melestarikan tinggalan budaya tersebut.
\end{abstract}

Kata kunci: seni hias tempel, tegel keramik, cerita Alkitab, Cirebon 


\section{PENDAHULUAN}

Cirebon mulai dikenal pada pertengahan abad ke-15an, sebagai pusat keagamaan, politik, dan ekonomi. Pada masa kekuasaan Sunan Gunung Jati akhir abad ke-15 menjadikan Cirebon sebagai pusat penyebaran agama Islam di pantai utara Jawa (Ambary 1996: 38). Cirebon merupakan pangkalan penting dalam jalur pelayaran dan perdagangan antar bangsa, membuatnya berperan sebagai jembatan antar budaya, sehingga banyak peninggalanpeninggalan purbakala, kesenian, dan warisan non fisik yang menjadi bukti tentang masuknya aneka ragam budaya dari berbagai penjuru dunia, antara lain Arab, India, Cina, dan Eropa, bahkan pada awal abad ke-18an Cirebon menjadi wilayah yang dikuasai oleh VOC (Lapian \& Sedyawati, 1996: 4-5). Beberapa bukti hubungan itu, tampak berbagai jenis keramik Cina dan Belanda menghias tembok-tembok keraton, makam, dan masjid. Beberapa ditandai dengan keberadaan tegel keramik bermotif cerita Alkitab yang berasal dari Delft Belanda, juga beberapa bangunan bergaya arsitektur Cina dan Eropa (Harkantiningsih, 2004: 4-15).
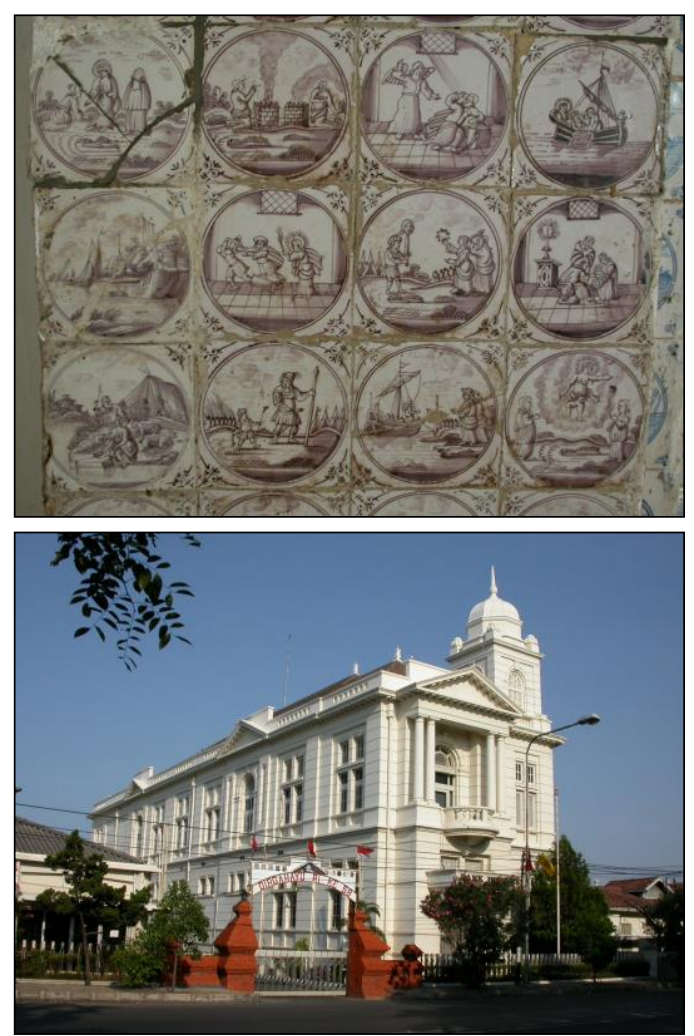

Cirebon sebagai kerajaan Islam, tidak hanya tumbuh dalam lingkup agama dan birokrasi, tetapi bersamaan dengan pertumbuhan itu, Cirebon berkembang pula sebagai kota tempat dibangunnya berbagai infrastruktur, untuk menunjang perannya sebagai jalur pelayaran dan perdagangan antar bangsa, sehingga terjadi percampuran dari berbagai budaya, baik nasional maupun internasional, terlebih berperannya VOC di wilayah ini (Harkantiningsih 2004: 13-15). Cirebon sebagai bandar internasional digambarkan pula oleh Tjandrasasmita (1996) bahwa sejak masa Sunan Gunung Jati, bandar Cirebon menjadi jaringan hubungan laut dan kunjungan bangsa Parsi, Mesir, Arab, Cina, India, dan Champa (Tjandrasasmita, 1996: 214). Kondisi ini lebih memperkuat adanya kebinekaan bangsa dan etnis pada masa itu. Masuknya keanekaragaman budaya yang saling pengaruh mempengaruhi, secara umum, berdampak pada percampuran budaya, hal ini tampak di berbagai tinggalan arkeologi, antara lain arsitektur bangunan, motif hias gunungan, kesenian, dan warisan non fisik (Harkantiningsih 1984; Lapian \& Sedyawati 1996: 4).
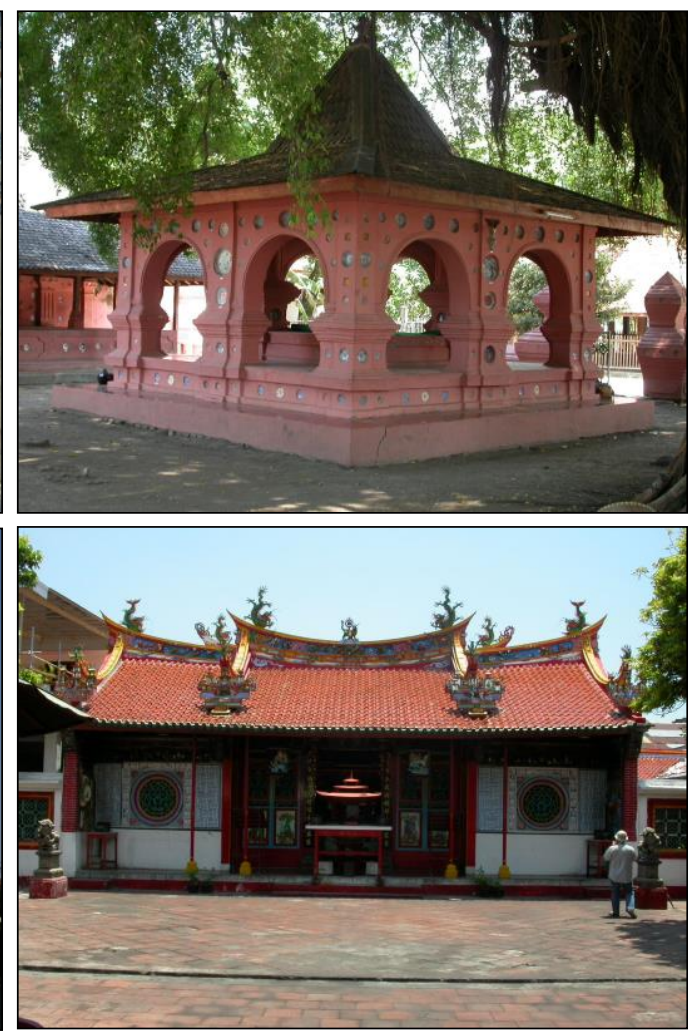

Gambar 1. Tegel keramik bermotif cerita Alkitab; berbagai jenis keramik Cina penghias tembok bangunan; rumah arsitektus Eropa dan Cina

(Sumber: Penulis, 2003) 
Saat ini pemerintah mencanangkan program Nawa Cita, dengan tema kebinekaan yang berada pada urutan kesembilan. Program ini juga menjadi bagian dalam penelitian arkeologi untuk memperteguh kebinekaan melalui peningkatan nilai-nilai keberagaman budaya serta melakukan penguatan karakter melalui pengajaran sejarah (NN, 2014: 29). Hasil penelitian arkeologi di wilayah Jawa Tengah bagian selatan dan Cirebon dapat dimaknai sebagai salah satu bukti penguatan karakter kebinekaan itu (Tim Penelitian, 1985; Tim Penelitian, 2003). Kajian arkeologi di Cirebon menunjukkan bahwa seni hias tempel keramik merupakan salah satu bukti warisan budaya yang unik. Keunikan ini tampak pada motif tegel-tegel keramik yang menceritakan isi Alkitab tentang Perjanjian Lama dan Perjanjian Baru. Tegel-tegel itu menjadi hiasan tempel tembok, baik di keraton, makam, masjid, maupun gua. Keunikan ini menjadi ciri khas budaya Cirebon, yang tentunya tidak hanya berkaitan dengan budaya seni, tetapi juga makna yang terkandung di dalam seni tersebut, serta kelestarian seni hias itu hingga kini di wilayah Cirebon.

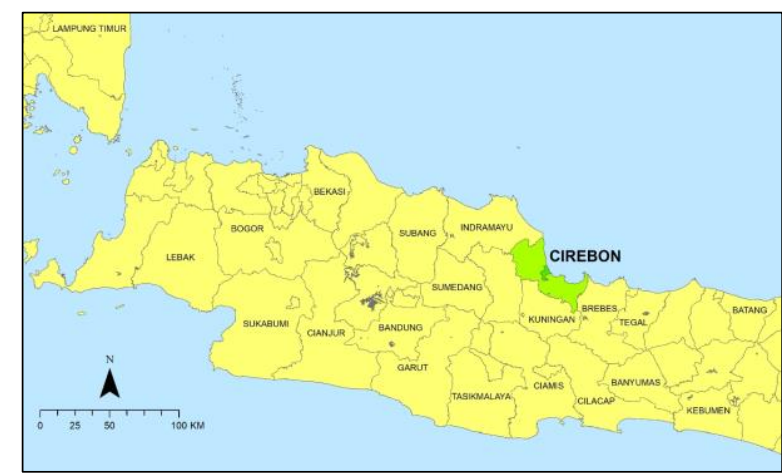

Gambar 2. Lokasi Cirebon

(Sumber: Peta Dasar BIG diolah oleh Penulis, 2017)

Pembahasan khusus tentang tegel keramik cerita Alkitab di Cirebon belum banyak ditulis. Paramatatya dan Ongkhodarma (2013) menulis dalam makalahnya berjudul Corak Ragam Hias Keramik Tempel di Keraton Kasepuhan dan Kanoman di Cirebon. Dalam bahasannya menitikberatkan tentang perbedaan dan persamaan seni hias tempel keramik di Keraton Kasepuhan dan Kanoman (Paramatatya \& Ongkhodarma, 2013) tidak secara spesifik membahas tentang cerita Alkitab pada tegel keramik. Mulyawati (1983) dalam skripsinya mengetengahkan tentang Keramik di Situs Astana
Gunung Jati Cirebon (Mulyawati, 1983), secara khusus membahas variabilitas keramik-keramik di Situs Astana. Demikian pula Linasari (1994) dalam skripsi yang ditulisnya menginformasikan tentang keanekaragaman Ragam Hias Keraton Kasepuhan dan Kanoman di Cirebon (Linasari, 1994), juga tidak secara khusus membahas tentang tegel Alkitab, tetapi ragam hias kaitannya dengan seluruh keramik di Keraton Kasepuhan dan Kanoman. Dalam pada itu, Harkatiningsih (2004) dalam monografinya telah menginformasikan tentang Seni Hias Tempel Keramik di Cirebon. Dalam monografi tersebut, pembahasan lebih diutamakan pada fungsi, makna, keindahan, dan keunikan teknologi berbagai jenis keramik sebagai hiasan tempel di bangunan profan dan sakral di wilayah Cirebon (Harkantiningsih, 2004).

Akhir-akhir ini, isu kebinekaan sedikit "dirisaukan," sebagaimana tampak dari kondisi di masyarakat yang cenderung semakin sulit menerima adanya perbedaan, termasuk hal-hal yang berkaitan dengan keagamaan. Namun, kondisi ini berbeda dengan yang terdapat di Cirebon. Keberadaan seni hias tempel keramik cerita Alkitab menimbulkan beberapa pertanyaan, yaitu bagaimana seni hias tempel tegel keramik ini terlestarikan? motif cerita Alkitab apa saja yang terdapat di dalam tegel keramik Cirebon? bagaimana pola persebaran dan kronologinya? apakah pelestarian seni hias tempel tegel keramik cerita Alkitab ini dapat dijadikan contoh toleransi kebinekaan untuk mengisi program Nawa Cita? pada kenyataannya menerima budaya asing dan beda kesepahaman masih dipertahankan hingga kini. Permasalahan ini dibahas melalui seni hias tempel tegel keramik cerita Alkitab. Berdasarkan permasalahan, maka tujuan penulisan ini adalah mengetahui alasan pelestarian seni hias tempel keramik yang berceritakan Alkitab, dan kaitannya dengan kebinekaan dalam program Nawa Cita dan kesepahaman penerimaan budaya asing di pusat pemerintahan dan bangunan sakral bercirikan Islam, serta pola persebaan dan motif yang tertera dalam tegel-tegel keramik itu.

Terlepas dari isi cerita tegel keramik tersebut, setidak-tidaknya hasil karya indah ini sampai saat kini masih terawat dan dapat dinikmati sebagai salah satu daya tarik kunjungan wisata budaya. Tentunya teknologi seni hias tempel keramik ini merupakan bukti tentang kebinekaan yang telah ada sejak masa lampau, khususnya di Kesultanan Cirebon. Kreativitas 
penggagas atau arsitek, untuk menggunakan keramik yang ada pada masa itu, mungkin memiliki makna tertentu dibaliknya.

\section{METODE}

Metode yang digunakan dalam pengolahan data, ialah analisis kualitatif, analisis konteks, dan studi pustaka. Studi pustaka dititikberatkan pada artikel yang berkaitan dengan seni tempel keramik, juga sejarah Cirebon. Masih sedikit tulisan tentang seni tempel tegel keramik cerita Alkitab. Beberapa yang ada hanya berkaitan dengan persebaran dan asal keramik, itupun ditulis pada tahun 1980an, atau tentang teknologi tegel keramik cerita Alkitab dari website. Demikian pula sumber sejarah yang diperlukan juga berasal dari tahun 1900. Walau tidak ada sumber terbaru, namun paling tidak sumbersumber acuan tersebut dapat menambah data perbandingan untuk membahas tulisan ini.

Analisis kualitatif untuk tegel keramik cerita Alkitab yang difungsikan sebagai penghias tembok keraton, masjid, makam, dan gua, meliputi ware, tipologi stilistik atau teknologi, dan kronologi. Dalam keramologi dikenal istilah ware, secara khusus diartikan sebagai sekumpulan ciri-ciri yang menunjuk tempat asal dan kronologi keramik dibuat. Ciri-ciri yang dimaksud antara lain: bahan (jenis, tekstur, porusitas, campuran, dan warna); glasir (warna, cara penerapan, kekedapan); dan hiasan, sedangkan tipologi dapat diamati melalui ciri-ciri, bentuk dan teknologi. Ciri-ciri atau atribut stilistik yang diamati meliputi motif hias, warna hias, dan susunan desain. Kadang-kadang ragam hias yang tampak hanya sebagian dari motif yang ada, namun ciri atribut kelengkapan tetap dapat diketahui secara kronologinya. Perpaduan ciri tersebut akan menghasilkan pertanggalan relatif, baik asal, jaman atau dinasti dan kronologi
(Harkantiningsih, 2010: 7-8). Analisis konteks dalam hal ini, yaitu hubungan tegel keramik dengan penempatannya dan temuan serta lainnya, misal keramik lainnya yang bukan tegel atau tinggalan lainnya yang berkorelasi dengan tegel keramik tersebut. Serangkaian proses itu akan menghasilkan jenis dan fungsi keramik yang berhubungan dengan kegiatan manusia masa lampau dan juga masa kini, yaitu adat istiadat dan kehidupan sosial (Harkantiningsih, 1980: 1). Data yang digunakan dalam analisis adalah tegel-tegel keramik khusus cerita Alkitab, hasil penelitian di Cirebon tahun 2003. Data ini pernah dipakai sebagai bahan penulisan dalam monografi bersamaan dengan keramik lainnya yang juga digunakan sebagai penghias tempel tembok, tetapi tidak terkait dengan kebinekaan dan toleransi.

\section{HASIL DAN PEMBAHASAN}

Cirebon merupakan pusat pemerintahan kerajaan Islam sekaligus jalur pelayaran dan perdagangan yang tumbuh dari abad ke-15 sampai abad ke-19, bahkan hingga saat kini. Cirebon dipandang penting perannya dalam mengungkapkan, baik sejarah lokal maupun regional pada periode yang rentangnya cukup panjang. Cirebon banyak dikunjungi para musafir antar bangsa dengan tujuan dagang dan belajar agama Islam (Lapian \& Sedyawati, 1996: 4). Berkumpulnya antar bangsa menyebabkan terjadinya percampuran antar budaya dan penerimaan budaya asing bagi masyarakat Cirebon. Salah satunya adalah seni hias tempel tegel keramik cerita Alkitab yang tampak di pusat kekuasaan dan keagamaan, yaitu Situs Keraton Kasepuhan, Masjid Abang Panjunan, Makam Sunan Gunung Jati, dan Gua Sunyaragi. Selain itu terdapat pula ciri arsitektur bangunan kolonial yang hingga kini masih berdiri.

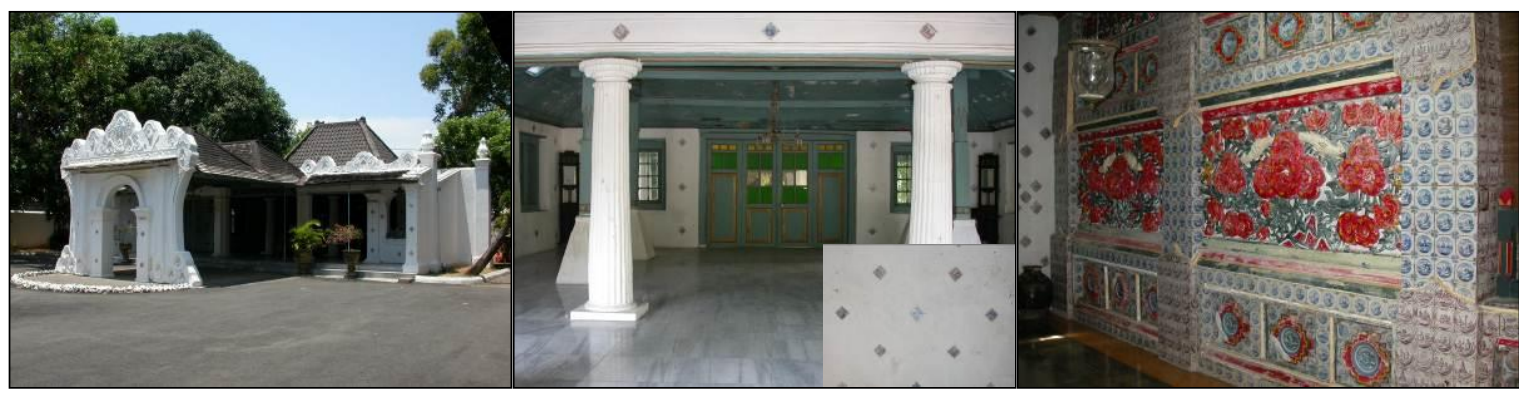

Gambar 3. Kerton Kasepuhan dan tegel keramik cerita Alkitab di Bangsal Agung (Sumber: Puslit Arkenas, 2003) 

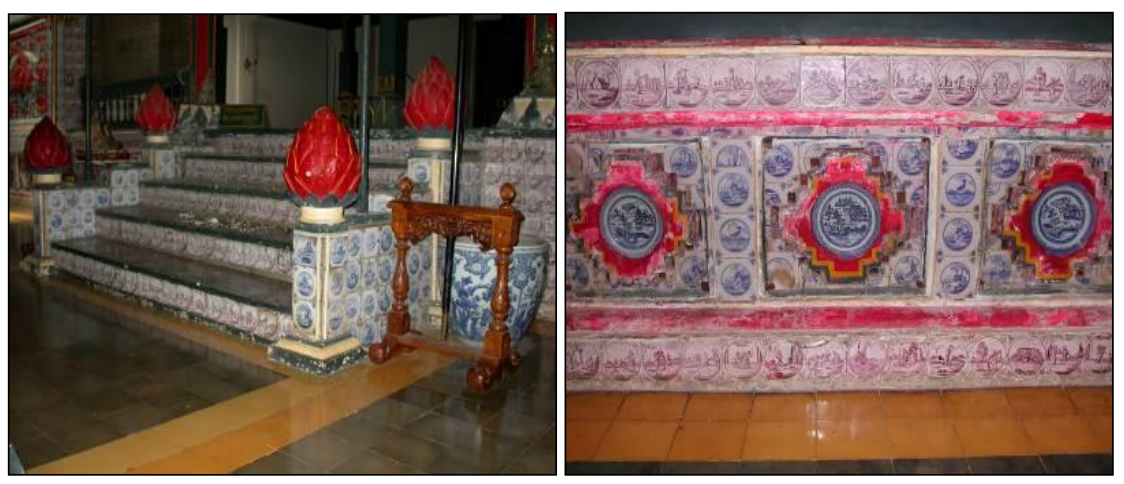

Gambar 4. Seni hias tempel di Bangsal Agung Panembahan (Sumber: Puslit Arkenas, 2003)

Keramik-keramik cerita Alkitab tersebut berbentuk segi empat, seperti halnya tegel keramik yang banyak digunakan untuk bangunan rumah, berukuran $13 \times 13 \mathrm{~cm}$, tebal $0,3 \mathrm{~cm}$, warna biru-putih serta coklat-putih. Cerita Alkitab yang tergambar di tegel keramik itu menggambarkan kisah tokoh-tokoh dalam Alkitab secara langsung atau kejadian sesungguhnya di lokasi. Penempelan di tembok tidak beraturan dan berurutan sesuai alur cerita. Ini menunjukkan bahwa pemasangan tegel cerita Alkitab tidak berdasarkan kepercayaan keagamaan, tetapi memang hanya sebagai seni hias atau dekorasi. Beberapa cerita yang dapat teridentifikasi dalam cerita Alkitab, antara lain:

\section{Keraton Kasepuhan}

Keraton Kasepuhan, merupakan pusat pemerintahan kedua setelah Keraton Pakungwati, yang dianggap sebagai cikal bakal dari seluruh keraton-keraton di wilayah Kesultanan Cirebon. Keraton Kasepuhan hingga kini masih berfungsi sebagai tempat tinggal Sultan Cirebon dan keluarganya. Seni hias tegel keramik yang ditempelkan di tembok ruangan Jinem Pangrawit, Gajah Nguling, Bangsal Pringgondani, Bangsal Prabayaksa, dan tembok pembatas menuju ke Bangsal Agung Panembahan, saling berhubungan dan terletak dalam satu bangunan sebagai bangunan utama Keraton Kasepuhan. Tegel-tegel dipasang miring terpencar tidak beraturan, sehingga posisi gambar-gambarnya juga tidak beraturan. Teknik penempelan keramik cerita Alkitab di ruangan Bangsal Agung Panembahan, ditempel dalam panel atau berjajar vertikal dan horizontal, namun tidak berurutan sesuai cerita atau kejadian; penempelan tegel-tegel ini di berselang-seling dengan keramik-keramik

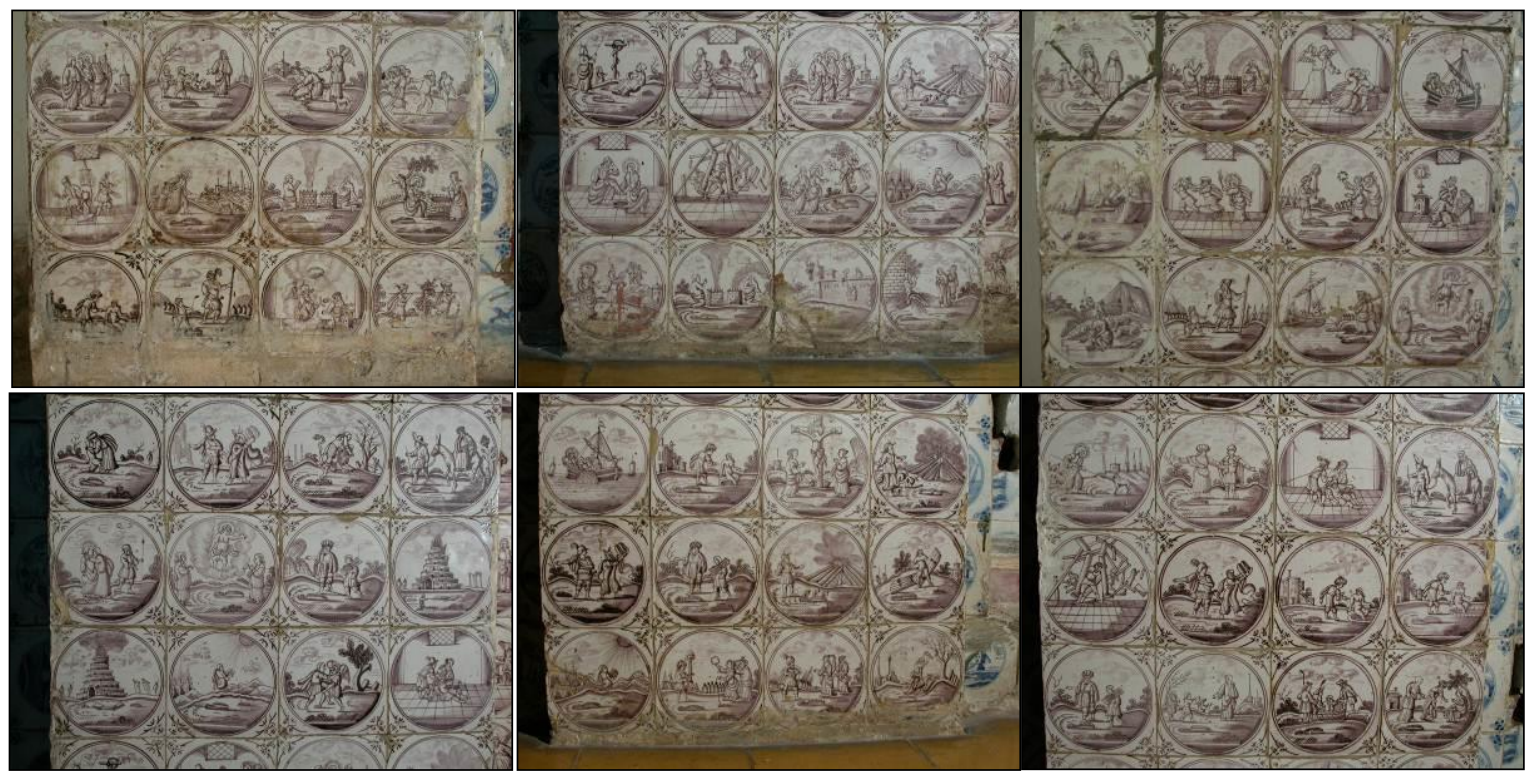

Gambar 5. beberapa motif tegel keramik cerita Alkitab (Sumber: Puslit Arkenas, 2003) 
bergambar non cerita, berbentuk piring warna biru-putih dan bunga teratai warna merah, serta sulur daun berwarna hijau ciri khas budaya Cina. Tegel keramik ini juga ditempelkan di anak tangga dan pelipit tangga Bangsal Agung Panembahan (Gambar 3 dan 4), (Harkantiningsih, 2004: 49-51)

\section{Tegel keramik cerita Alkitab, kompleks Keraton Kasepuhan}

Motif hias tegel-tegel tersebut, yaitu:

Cerita dalam Kitab Perjanjian Lama

1. Adam dan Hawa diusir dari Taman Eden oleh seorang malaikat (Kejadian 3: 23-24);

2. Kain berupaya membunuh Habel (Kejadian 4: 8)

3. Yakub diberkati Ishak menjadi anak sulung (Kejadian 27)

4. Yakub bergumul dengan malaikat Allah di Yabok (Kejadian 32: 22-32)

5. Daud bermain kecapi di hadapan Raja Saul, disaksikan oleh seorang hamba Saul (I Samuel 16: 16-23)

6. Daud menggembala domba di padang (I Samuel 16: 11)

7. Daud melawan Goliat (I Samuel 17: 40-54)

8. Goliat mati terkapar di tanah (I Samuel 17: 49)

9. Putri Firaun menemukan bayi Musa di dalam keranjang di Sungai Nil (Keluaran 2: 5-6)

10. Musa mengulurkan tongkat membelah Laut Teberau agar bangsa Israel dapat menyeberang, sebuah kereta kuda pasukan Mesir tenggelam ke dalam laut (Keluaran 14: 15-28)

11. Musa melarikan diri dari istana Firaun (Keluaran 2: 15)

12. Musa di Gunung Sinai membawa 2 loh batu tulisan jari Allah (Keluaran 31: 18)

13. Harun dan bangsa Israel menyembah lembu emas (Keluaran 32: 1-6)

14. Sejumlah anak-anak yang menghina Elisa sedang dikejar-kejar binatang buas (2 Rajaraja 2: 23-24)

15. Air bah datang dan orang-orang berusaha menyelamatkan diri (Kejadian 7: 19-23)

16. Abraham berpisah dengan Lot keponakannya dan membagikan tanah pusakanya (Kejadian 13: 8-12)

17. Yusuf akan dibuang ke sumur oleh saudarasaudaranya (Kejadian 37: 23-24)
18. Yusuf ditarik pakaiannya oleh istri Potifar yang duduk di tempat tidur (Kejadian 39: 620)

19. Yunus duduk di bawah pohon Jarak yang tumbuh membesar dalam semalam (Yunus 4: 6-11)

20. Ayub laki-laki yang penuh koreng berpakaian compang-camping duduk di tanah dan dilempari batu oleh seseorang (Ayub 2: 7-8)

21. Simson bergulat dengan singa (Hakimhakim 14: 5-6)

22. Simson mengamuk merobohkan tiang-tiang bangunan besar (Hakim-hakim 16: 28-30)

23. Dua wanita memperebutkan seorang bayi di Istana Salomo (I Raja-raja 3: 16-28)

24. Kota dan Menara Babel tempat Allah mengacaukan bahasa manusia menjadi berbeda-beda (Kejadian 11: 1-9)

25. Bileam menunggangi keledai betina yang bijak, yang tidak mau terus melangkah karena dihalangi malaikat membawa pedang (Bilangan 22: 21-35)

26. Lot membawa kedua anak perempuannya keluar dari Zoar ke pegunungan (Kejadian 19: 30)

27. Elia naik ke langit dengan kereta kuda berapi (2 Raja-raja 2: 11-14)

28. Perahu Nuh dengan berbagai binatang yang akan masuk kedalamnya (Kejadian 7: 14-16)

29. Kain dan Habel membakar persembahan di atas mezbah (Kejadian 4: 3-5)

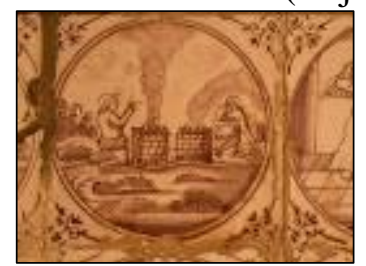

30. Musa dan ular tembaga (Bilangan 21: 4-9)

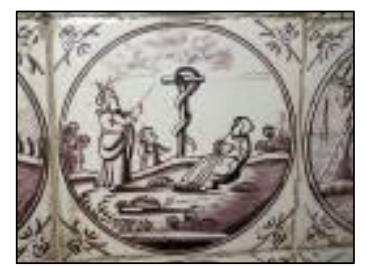

(Harkantiningsih, 2004: 24-26)

\section{Cerita dalam Kitab Perjanjian Baru}

1. Maria didatangi Malaikat Gabriel (Lukas 1: 26-38)

2. Yusuf didatangi malaikat memberitahu hal kelahiran Yesus (Matius 2: 13) 
3. Tiga orang Majus berada di padang mencari petunjuk bintang (Matius 2: 1-12)

4. Yesus marah di Bait Allah yang dipakai untuk berdagang (Matius 21: 12-13)

5. Yohanes Pembaptis membaptiskan Yesus, tampak merpati di atas kepala Yesus (Markus 1: 9-11)

6. Maria dan Yusuf membawa bayi Yesus ke Mesir (Matius 2: 13-15)

7. Yesus menaiki keledai dan dielu-elukan penduduk Kota Yerusalem (Lukas 19: 28-38)

8. Orang Samaria yang baik hati menolong orang tak dikenal (Lukas 10: 30-37)

9. Seorang laki-laki merampok dan menyiksa seseorang hingga terkapar di jalan antara Yerusalem dan Yeriko (Lukas 10: 30)

10. Seorang terluka sedang ditolong oleh orang Samaria (Lukas 10: 33-35)

11. Elizabeth wanita dengan sinar di kepalanya sedang mengandung Yohanes Pembaptis berdiri berhadapan dengan Zakaria suaminya (Lukas 1: 24-25)

12. Yesus berdoa di Taman Getsemani (Lukas 22: 39-46)

13. Yesus duduk berkhotbah di tengah muridmuridnya (Matius 5: 1-12)

14. Yesus memanggil murid-muridnya yang pertama Simon Petrus dan Andreas (Matius 4: 18-22)

15. Yesus memberkati anak-anak (Lukas 18: 1517)

16. Yesus bersama seorang wanita di sumur di Sikhar Samaria (Yohanes 4: 1-42)

17. Zakheus naik pohon ingin melihat Yesus (Lukas 19: 1-10)

18. Yesus membasuh kaki muridnya (Yohanes 13: 1-20)

19. Yudas Iskariot mencium Yesus di hadapan para prajurit, Yudas mengkhianati Yesus (Lukas 22: 47-48)

20. Paulus dan Silas di dalam penjara Filipi dipasung kakinya (Kisah Rasul 16: 24-25)

21. Yohanes Pembaptis dipotong lehernya di hadapan 2 orang wanita, Herodias dan putrinya (Matius 14: 1-12)

22. Kepala Yohanes Pembaptis diserahkan seseorang kepada Putri Herodias (Matius 14: 11)

23. Petrus menjala ikan di Danau Genesaret, mendapat banyak sekali ikan (Lukas 5: 5-11)

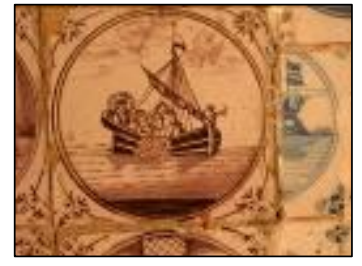

24.Yesus berkhotbah di atas perahu (Lukas 5: 3)

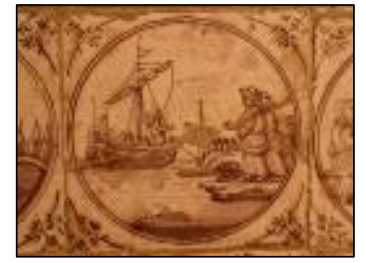

25.Yesus disalibkan, di atas salib bertuliskan "Raja Orang Yahudi" (Markus 15: 25)

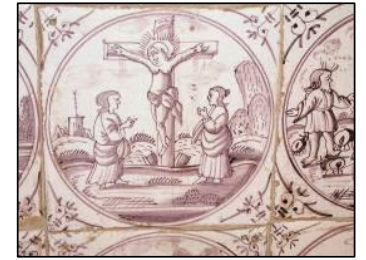

26.Yesus memikul salib disaksikan beberapa orang (Yohanes 19: 16b)

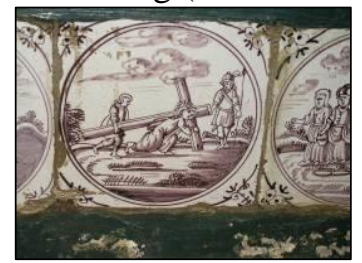

27. Paulus dan kapal yang terombang-ambing di laut (Kisah Para Rasul 27: 18-44)

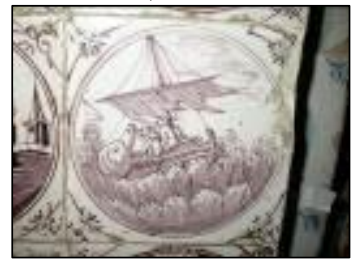

28. Saulus terkena sinar dari langit hingga buta dan jatuh ke tanah (Kisah Rasul 9: 1-9)

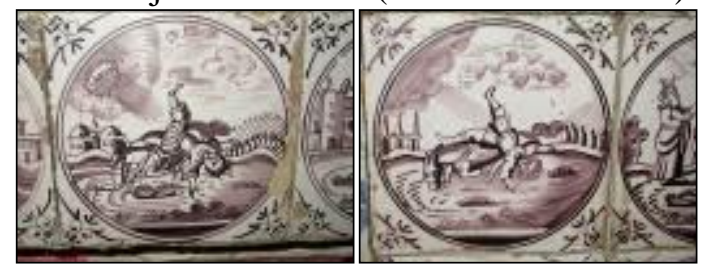

29. Yesus menampakkan diri kepada 2 murid ke Emaus (Lukas 24: 13-35)

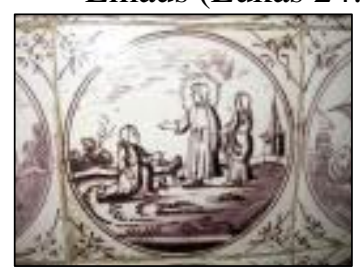


30. Simon Petrus menjala ikan sesuai perintah Yesus (Lukas 5: 4-10)

31.Kelahiran Yesus (Lukas 2: 1-7)

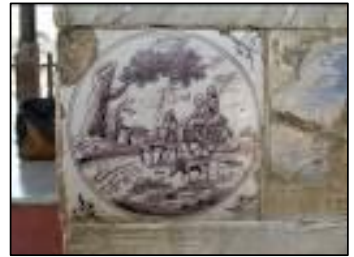

32. Yesus membasuh kaki muridnya (Yohanes 13: 1-20)

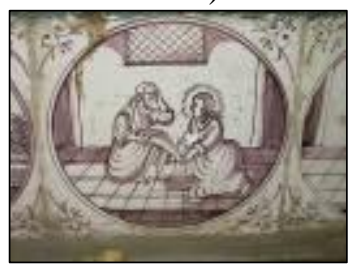

(Harkantiningsih 2004: 26-32)

\section{Masjid Abang Panjunan}

Masjid Abang Panjunan dibangun oleh Syekh Abdurrachman. Cat tembok masjid warna abang (merah) dan terletak di Desa Panjunan, oleh karena itu mesjid ini disebut Masjid Abang Panjunan. Tegel keramik cerita Alkitab yang terdapat di Masjid ini yaitu Daud sedang memainkan kecapi di hadapan Raja Saul dan disaksikan oleh seseorang yang berdiri di sisi Raja. Tegel keramik ini ditempelkan pada tembok bergapura paduraksa (Harkantiningsih, 2004: 51-54).

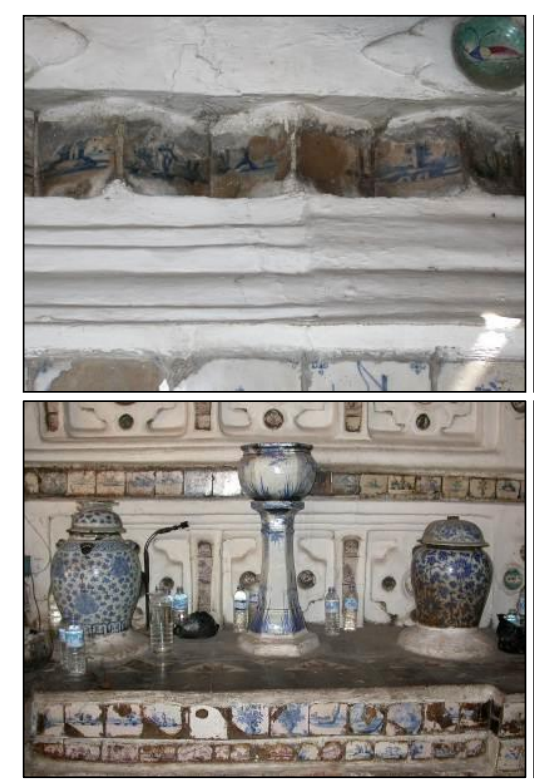

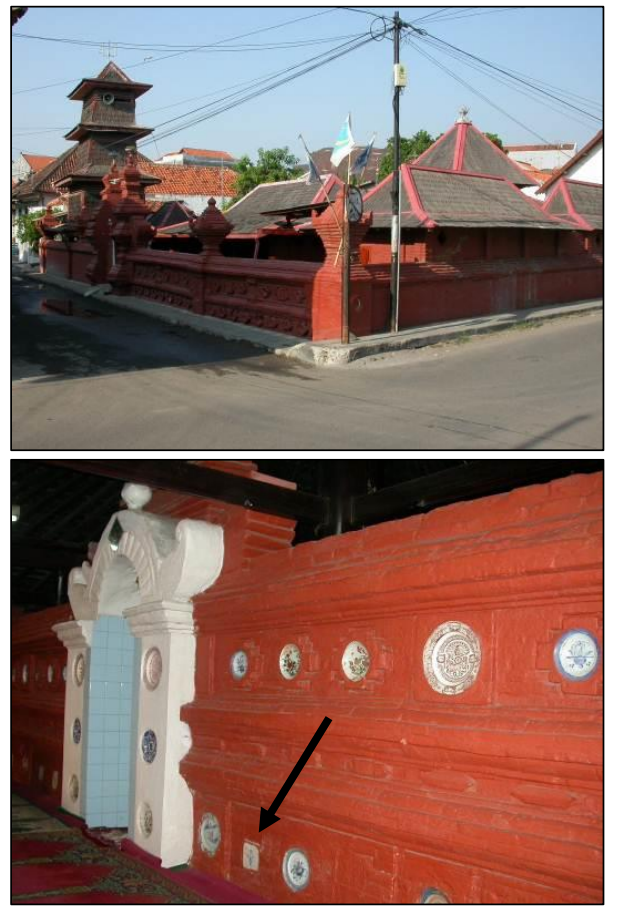

Gambar 6. Masjid Abang Panjunan, Daud bermain kecapi di hadapan Raja Saul, disaksikan oleh seorang laki-laki (I Samuel 16: 16-23), tanda panah (Sumber: Puslit Arkenas, 2003)

\section{Makam Sunan Gunung Jati}

Kompleks makam terbesar dan dianggap keramat, merupakan makam Sunan Gunung Jati dan makam raja-raja keturunan Kesultanan Cirebon. Tegel keramik cerita Alkitab ditempel di bagian pelipit dinding tembok. Teknik tempel

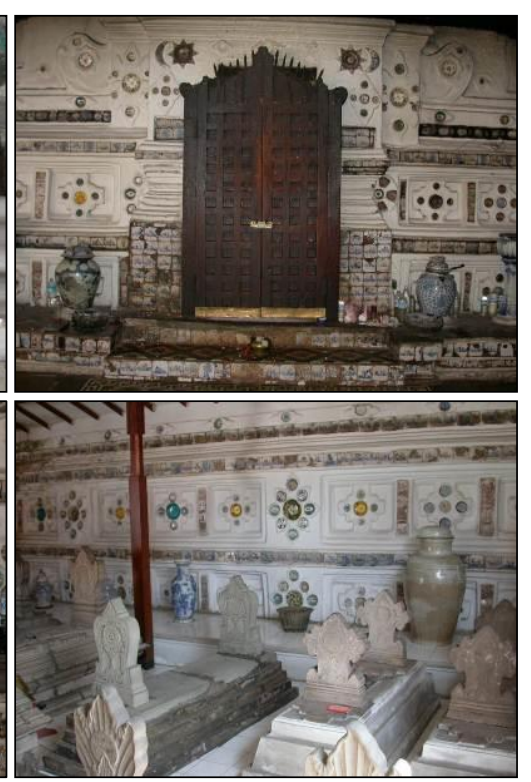

Gambar 7. Tegel keramik cerita Alkitab ditempel di bagian pelipit tembok (atas dan bawah)

(Sumber: Puslit Arkenas, 2003) 
secara vertikal dan horizontal, di selang-seling dengan keramik-keramik lainnya, tidak beraturan antara tegel biru-putih dan tegel coklat-putih (Harkantiningsih, 2004: 54-60).

\section{Kompleks Gua Sunyaragi}

Bangunan Sunyaragi merupakan bangunan Tamansari yang difungsikan sebagai tempat berkhalwat atau menyepi dan juga sebagai tempat rekreasi. Bangunan ini dibuat dari susunan bata dan batu karang yang membentuk gunungan atau awan. Gua Sunyaragi didirikan pada abad ke-18. Tegel keramik cerita Alkitab terdapat di setinggil pendopo, di bagian pelipit; sebagian besar tegel telah rusak, karena lepas dari lapisan dinding (Harkantiningsih, 2004: 62-65). Falah (1996) menjelaskan, bahwa menyepi atau bertapa berkaitan dengan kegiatan keagaman, mendekatkan diri pada Tuhan dan menjauhkan diri dari keramian. Sunya ragi atau kosong jasmani keadaan yang dicapai pada waktu bertapa atau menyepi (Falah, 1996: 68).

Keberadaan seni hias tempel ini tentu tidak terlepas dari keberadaan Belanda-VOC-Hindia Belanda di Cirebon. Pada masa itu, banyak kebijakan-kebijakan yang dilakukan secara bersama (Lapian \& Sedyawati, 1996: 5). Terlebih pada akhir abad ke-17 VOC berhasil menanamkan dominasinya di wilayah Cirebon, sehingga VOC berhak menguasai perdagangan dan pelayaran lokal, termasuk kebijakan pertanian dan harga jual hasilnya. Dampak dari ini, baik politis, ekonomi, dan militer berada di bawah kontrol Kompeni (Sulistyono ,1996: 121). Mungkin hal ini pulalah yang menyebabkan keberadaan seni hias tempel tegel keramik cerita Alkitab di wilayah Cirebon akibat interaksi dan pengaruh minat motif hias dari Eropa.
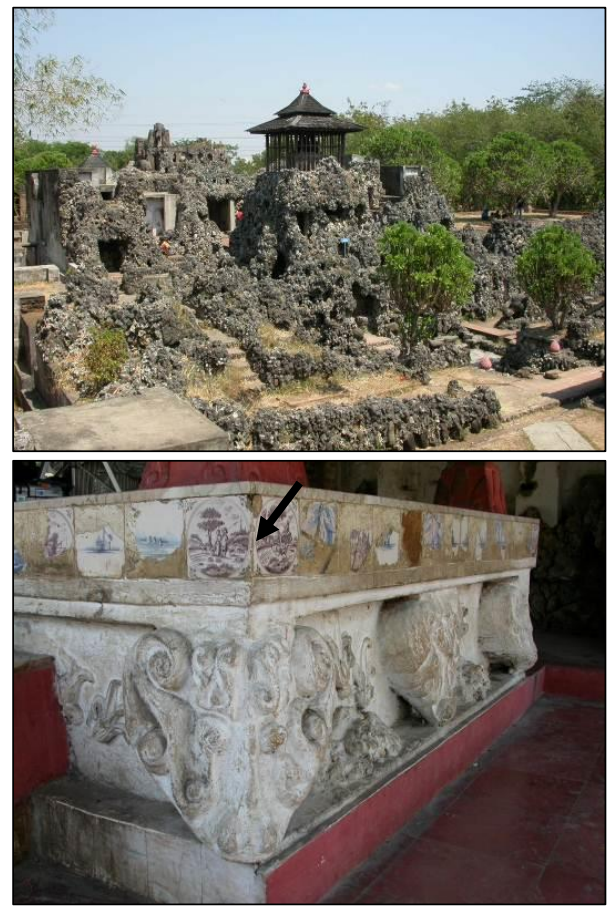

Gambar 8. Gua Sunyaragi dan tegel keramik cerita Alkitab dibagian pelipit

(Sumber: Puslit Arkenas, 2003)

Periode awal masa Kesultanan Cirebon berada pada abad ke-15an, ditandai dengan berdirinya Dalem Agung Pakungwati. Pakungwati diperluas dan menjadi Keraton Kasepuhan, kronologi tegel keramik berasal dari Delf Belanda abad ke-17an (Jorg, 1984: 18-19). Demikian pula, tegel keramik (Delf Belanda abad ke-17) yang berada di Makam Sunan Gunung Jati (abad ke-16 akhir), Masjid Abang Panjunan (abad ke-15) hanya 1 tegel keramik juga dari Delf Belanda abad ke-17, sedangkan tegel keramik di Gua Sunyaragi (abad ke-18), juga berasal dari Delf Belanda abad ke-17. Apabila kronologi tegel keramik ini dibandingkan dengan kronologi keramik lainnya, yang juga difungsikan sebagai
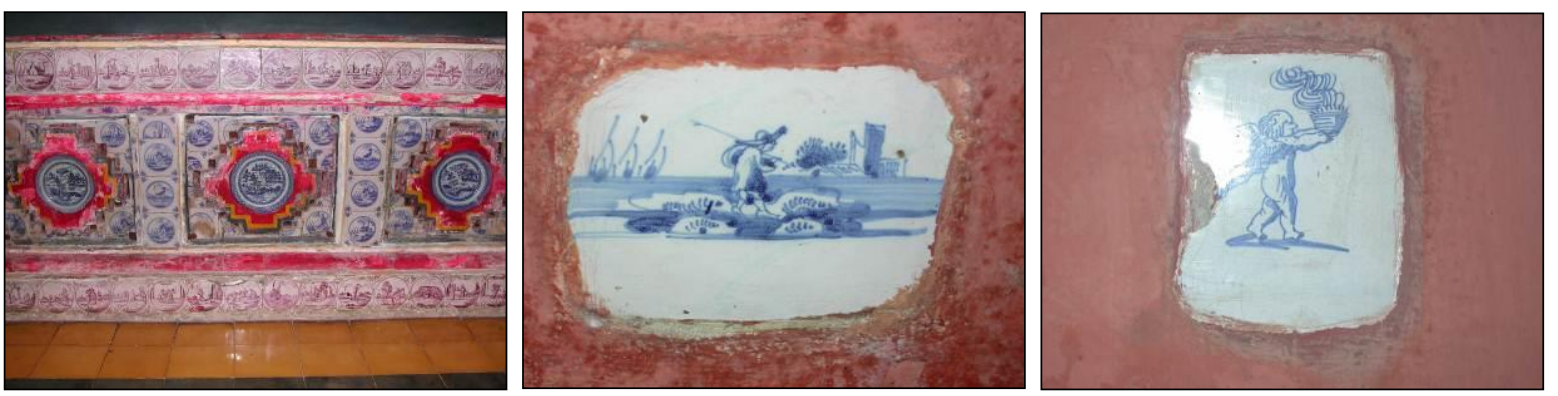

Gambar 9. Keraton Kasepuhan keramik non cerita Belanda dan Cina abad ke-17-19

(Sumber: Puslit Arkenas, 2003) 


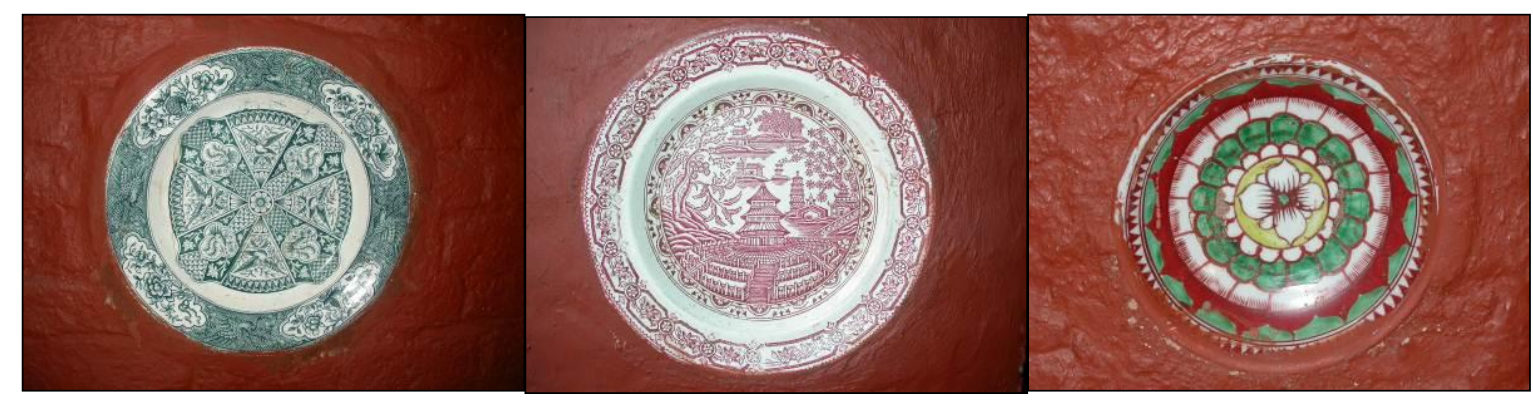

Gambar 10. Masjid Abang Panjunan: Keramik non cerita Belanda dan Cina abad ke-17-19

(Sumber: Puslit Arkenas, 2003)

seni hias tempel tembok/dinding, menunjukkan adanya persamaan kronologi. Seni hias keramik non cerita di Keraton Kasepuhanu berasal dari Belanda dan Cina abad ke-17-19. Pada Masjid Abang Panjunan, sebagian besar seni hias keramik berasal dari Cina dan Belanda abad ke17-19. Pada Makam Sunan Gunung Jati, keramik berasal dari Jepang dan berasal dari Cina abad ke-19-20, dan berasal dari Belanda abad ke-19-20 (Harkantiningsih, 2004).

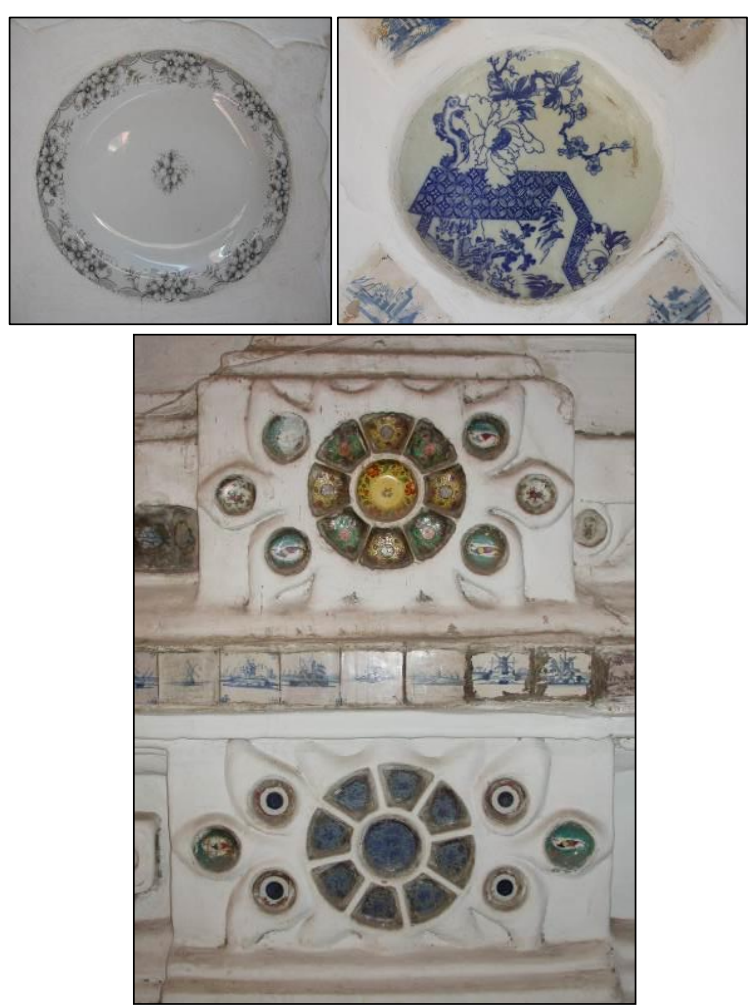

Gambar 11. Makam Sunan Gunung Jati: keramik non cerita Belanda, Jepang, buatan Cina abad 19-20 (Sumber: Puslit Arkenas, 2003)

Dari perbandingan kronologi tegel keramik cerita Alkitab dengan keramik lainnya, yang difungsikan sebagai hiasan tempel tembok, tampak memiliki persamaan kronologi. Sementara itu, kronologi dengan pembangunan keraton, makam, masjid tidak terkorelasi, berarti pemasangan tegel keramik cerita Alkitab tidak bersamaan dengan pembangunan, sedangkan di Gua Sunyaragi kronologi tegel keramik terkorelasi dengan pembangunan gua, sehingga dapat diartikan pemasangan bersamaan antara hias tempel keramik dengan bangunan.

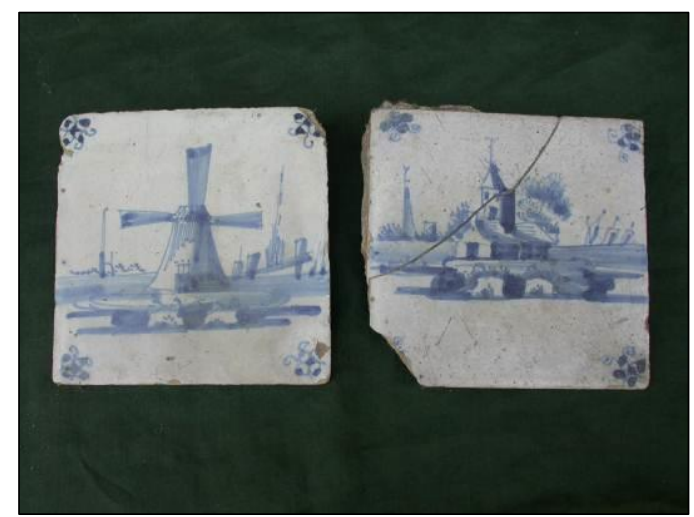

Gambar 12. Gua Sunyaragi: keramik non cerita Delf Belanda abad ke-18-19

(Sumber: Puslit Arkenas, 2003)

Keberadaan seni hias keramik dari berbagai asal dan jenis di wilayah Kesultanan Cirebon, dapat dikaitkan pula sebagai dampak perkawinan antara Sunan Gunung Jati dengan seorang putri Kaisar Cina bernama Ong Tien Nio yang masuk Islam (Harkantiningsih, 2004: 10), sehingga dapat dipahami alasan pelestarian tinggalan budaya tersebut, karena sebagai peringatan salah satu istri sultan yang sangat berpengaruh pada masa itu.

Apabila dikaitkan keberadaan seni hias tegel keramik cerita Alkitab dengan Cirebon sebagai pusat kerajaan Islam, mungkin tidak terlepas karena peran Belanda-VOC pada masa itu. Kepercayaan dan kerjasama dengan Kompeni mempengaruhi kebijakan dalam semua bidang 

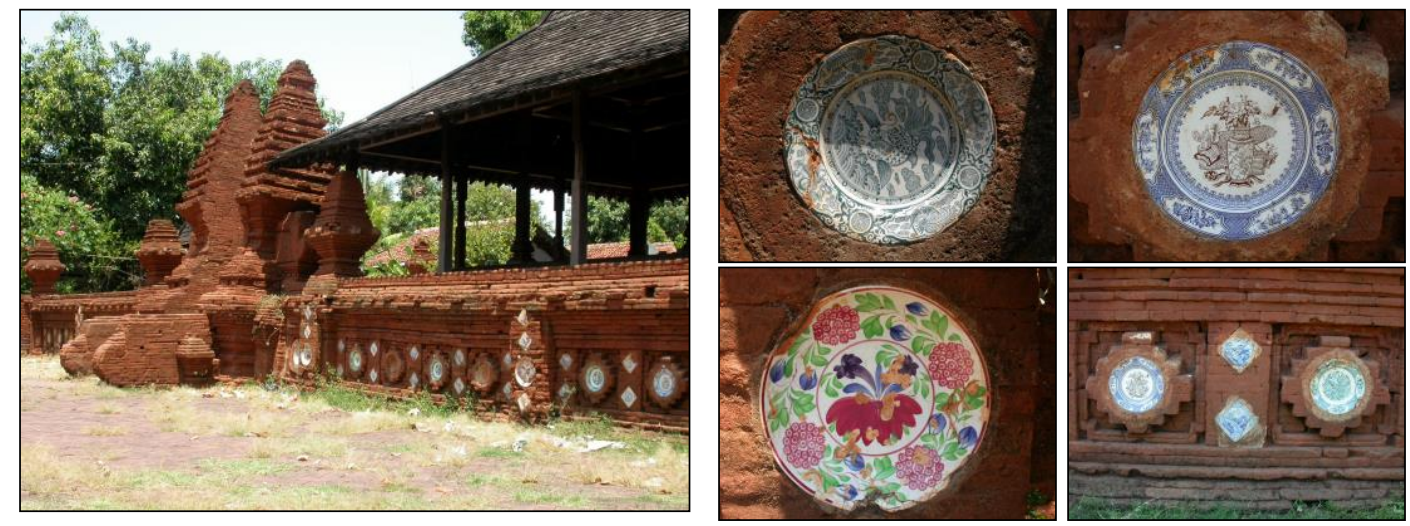

Gambar 13. Seni hias tempel keramik di Keraton Pakungwati (Sumber: Penulis, 2003)

yang sebagian besar ditentukan oleh Belanda. VOC berkuasa penuh terutama sejak perjanjian Cirebon-VOC akhir abad ke-17 (Tjandrasasmita, 1996: 210-215). Pada masa perjalanan kekuasaan VOC itulah, Belanda merubah tata bangunan, mungkin termasuk menambahkan tegel keramik cerita Alkitab ataupun keramik lainnya di seluruh bangunan Cirebon. Dugaan ini diperkuat kronologi keramik yang tidak terkorelasi dengan kronologi bangunan keraton, makam, masjid, kecuali Gua Sunyaragi. Seni tempel keramik didominasi dari Belanda, Jepang, dan Cina termasuk keramik buatan Cina dari abad ke-17-20. Hipotesis ini diperkuat keberadaan seni hias tempel keramik di Pakungwati yang berasal dari Maastrich Belanda abad ke-18-20, sedangkan keraton didirikan pada abad ke-15. Juga teknik penempelan yang sangat kasar tidak serapi apabila dipasang dari awal pembangunan.
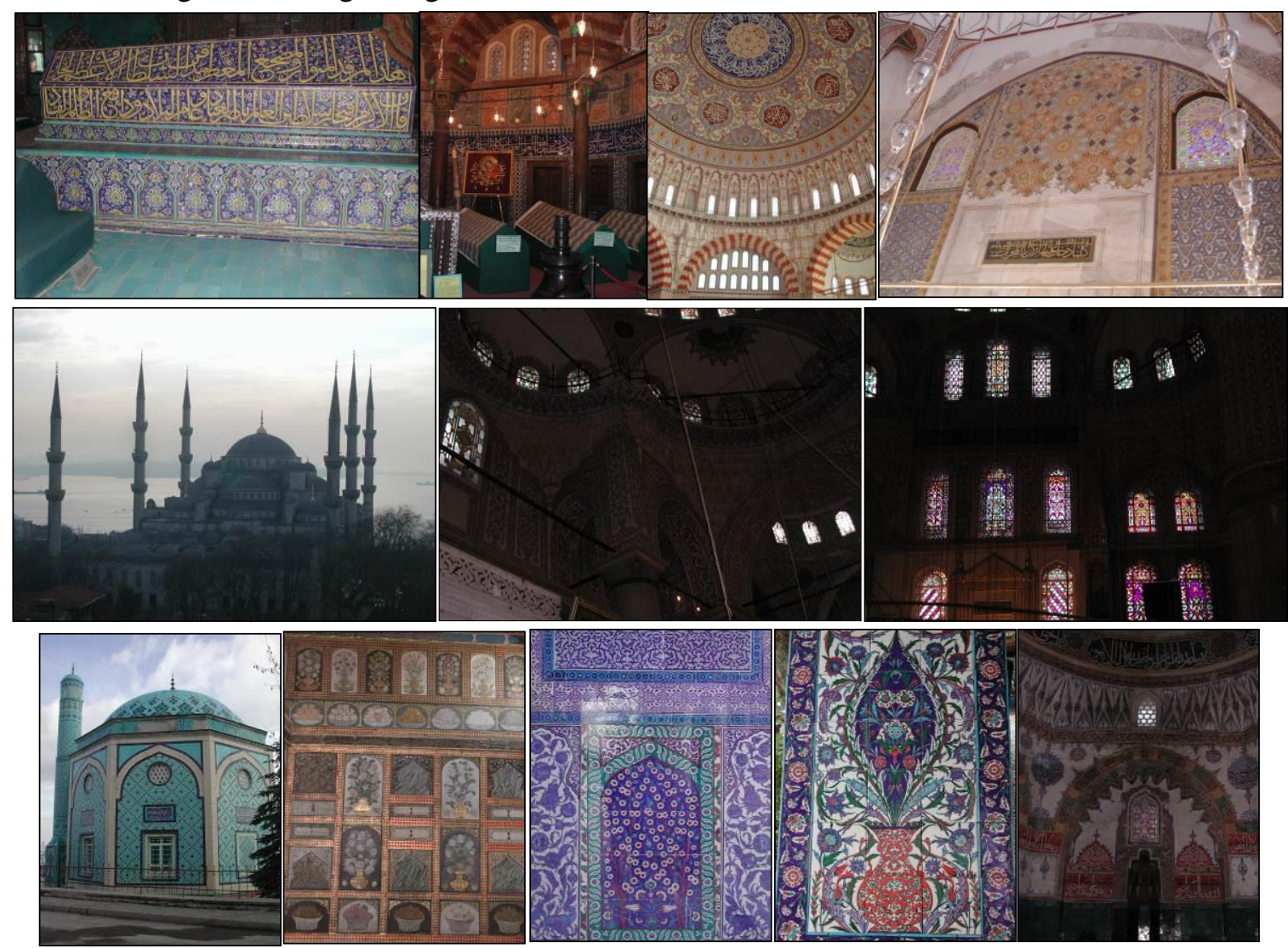

Gambar 14. Bangunan masjid dan makam dengan seni hias tegel keramik di Turki (Sumber: Penulis, 2010) 
Keberadaan seni hias tempel keramik, dapat juga dihubungkan dengan pembenahan terhadap kota dan infrastrukturnya yang dilakukan oleh Belanda terutama pada abad 1920, setelah Cirebon dijadikan sebagai gemeente. Pada saat inilah Cirebon dapat dikatakan sebagai kota kolonial yang menyimpan berbagai buktibukti peninggalan sejarah yang sangat banyak (Sulistyono, 1996: 14-141).

Teknik seni hias tempel tegel keramik ini sebenarnya telah dikenal sejak abad ke-16 di daratan Eropa, antara lain Portugis, Spanyol, dan Belanda serta beberapa bangunan suci Muslim di Asia (NN, 1993). Hingga kini seni hias keramik juga terdapat di bangunan suci Istambul, Turki antara lain, Masjid Biru dan Hagia Shopia yang pada awalnya merupakan gereja kemudian menjadi masjid, dan kini sebagai museum; juga di beberapa bangunan masjid di Bursa, Konya, dan Edime. Bangunan-bangunan tersebut berasal dari abad ke-13-16an.

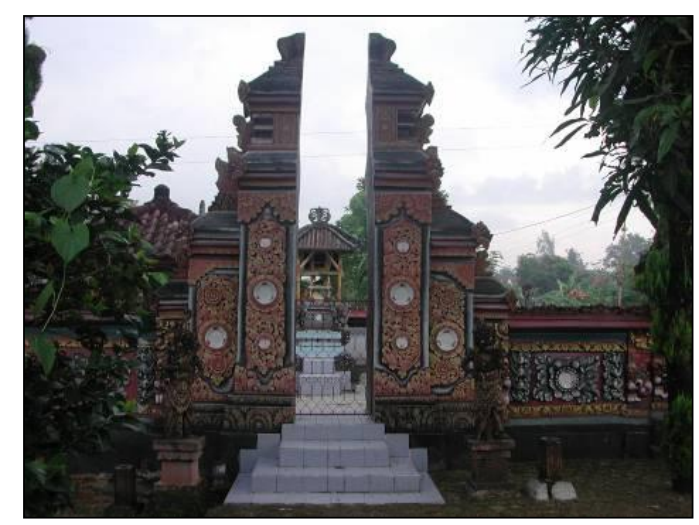

Gambar 15. Salah satu gerbang pura di Lampung Selatan dengan seni hias tempel keramik modern

(Sumber: Penulis, 2008)

Seni hias tempel tegel keramik merupakan budaya universal, dapat diterima di penjuru dunia, baik di bangunan profan maupun sakral, sebagai contoh Indonesia dan Turki. Hingga kini pun seni hias tempek keramik juga masih dilakukan di bangunan suci pura di Lampung Selatan, walau keramik yang ditempelkan adalah piring-piring baru.

\section{KESIMPULAN}

Cirebon dikenal sebagai pusat perkembangan dan penyebaran Islam, sekaligus pusat ekonomi, sosial, politik, dan budaya. Saat ini, Cirebon merupakan wilayah tujuan wisata budaya dan wisata ziarah. Sebagai kota bandar, pusat segala aktivitas kehidupan, banyak terjadi kontak budaya dengan pendatang lokal, nasional, maupun internasional. Salah satu bukti kontak budaya itu adalah seni hias tempel tegel keramik cerita Alkitab yang hingga kini masih terlestarikan, hal ini membuktikan adanya toleransi masyarakat saat kini. Dapat diartikan pula, bahwa masyarakat menjunjung tinggi simbol-simbol yang berada di keraton, makam, masjid, dan gua, yang dianggap sebagai tempat penting pada masa lalu bahkan masa sekarang, sekaligus sebagai tempat religius. Keberadaan di tempat yang dianggap suci oleh masyarakat, juga mempengaruhi pelestarian seni hias tegel keramik cerita Alkitab tersebut. Ini menunjukkan adanya toleransi ataupun kebersamaan dari adanya keberagaman, karena masyarakat dikenal toleran dan memiliki kearifan lokal dalam menerima perbedaan yang ada dan itu merupakan tinggalan budaya nenek moyang yang perlu dilestarikan.

Adanya pemahaman, bahwa Islam dapat berakulturasi dengan budaya lainnya. Oleh karena itu, pelestarian tinggalan budaya yang sangat spesifik ini perlu ditingkatkan dan dilakukan secara berkesinambungan, selain untuk pengingat sejarah, juga sebagai contoh adanya toleransi kebinekaan yang sangat diperlukan dalam rangka persatuan dan kesatuan bangsa, salah satu yang dapat ditiru adalah Cirebon. Keindahan, ciri khas, dan tinggalan sejarah ini jangan sampai dirusak ataupun dihilangkan karena alasan-alasan tertentu. Terlepas dari isi cerita atau penggambaran tersebut, setidaknya hasil karya indah ini sampai kini masih terawat dan dapat dinikmati atau bahkan menjadi salah satu daya tarik tersendiri, baik oleh para ilmuwan, keramolog, maupun wisatawan. Kelestarian seni hias ini mungkin dapat pula dihubungkan dengan toleransi kebinekaan yang menjadi program kebijakan pemerintah.

Seni hias keramik ini merupakan salah satu tinggalan cagar budaya yang perlu dilestarikan dan dimanfaatkan, sesuai aturan yang tertulis dalam Undang-Undang Republik Indonesia Tentang Cagar Budaya (Indonesia, 2011), maka tinggalan ini harus diselamatkan, dimanfaatkan, dan dilestarikan, baik untuk kepentingan agama, sosial, pariwisata, pendidikan, dan kebudayaan. Selain itu, data tersebut dapat menjadi refeensi untuk merekonstruksi budaya serta tata sosial kehidupan pada masa lalu antara masyarakat lokal dengan pendatang, dalam hal ini bangsa-bangsa asing yang sempat berhubungan dengan wilayah 
Cirebon. Seni hias ini menjadi warisan budaya dan apresiasi masyarakat Cirebon terhadap tinggalan budayanya.

Seni hias ini juga dapat dijadikan contoh toleransi kebinekaan untuk mengisi program Nawa Cita, karena masih mempertahankan warisan budaya, walau itu tidak sesuai dengan kepercayaan yang dianutnya, tetapi pada kenyataannya masih dapat menerima dan mempertahankan beda kesepahaman terhadap seni hias itu hingga kini. Pelestarian ini tidak terkait dengan cerita atau gambar dari motif keramik terlebih agama, tetapi karena pengakuan sebagai warisan budaya yang perlu dilestarikan. Pada dasarnya keberadaan seni hias ini karena persahabatan antara penguasa pada waktu itu, baik Kesultanan maupun Belanda, sehingga memungkinkan keramik cerita Alkitab diterima oleh masyarakat sebagai hiasan bangunan, sehingga disepakati tanpa melanggar norma dan nilai-nilai budaya lokal. Hal ini dapat dianggap bukan sebagai bentuk intervensi pihak VOC, atau dapat juga dipahami bahwa masyarakat lokal pada masa itu sangat terbuka dengan unsur budaya asing, pada masa puncak hubungan kerjasama ekonomi, sosial, budaya sangat terbuka tanpa kehilangan nilai-nilai kearifan lokalnya.

\section{Ucapan Terima Kasih}

Penulis mengucapkan terima kasih yang besar kepada seluruh pihak yang terlibat dalam pengembangan tulisan ini. Terima kasih kepada seluruh Dewan Redaksi dan Mitra Bebestari Kapata Arkeologi yang telah memberikan beragam masukan dan saran yang berarti untuk menyempurnakan tulisan ini hingga bisa dipublikasikan. Semoga tulisan ini dapat bermanfaat bagi ilmu pengetahuan.

$* * * * *$

\section{DAFTAR PUSTAKA}

Ambary, H. M. (1996). Peranan Cirebon Sebagai Pusat Perkembangan dan Penyebaran Islam. In Zuhdi, S. (Ed.), Cirebon Sebagai Bandar Jalur Sutra. Kumpulan Makalah Diskusi Ilmiah (pp. 35-53). Jakarta: Departemen Pendidikan dan Kebudayaan Republik Indonesia.
Falah, W. A. (1996). Tinjauan Konsepsi Seni Bangunan Istana Peninggalan Masa Islam di Kesultanan Cirebon dalam Konteks Kesinambungan Budaya. In Zuhdi, S. (Ed.), Cirebon Sebagai Bandar Jalur Sutra. Kumpulan Makalah Diskusi Ilmiah (pp. 55-75). Jakarta: Departemen Pendidikan dan Kebudayaan Republik Indonesia.

Harkantiningsih, N. (1980). Keramik di Situs Pabean Banten: Sebuah Penelitian Pendahuluan. Skripsi, Universitas Indonesia.

Harkantiningsih, N. (1984). Beberapa Peninggalan Masa Islam di Jawa Tengah Bagian Selatan. Jakarta: Pusat Penelitian Arkeologi Nasional.

Harkantiningsih, N. (2004). Monografi Seni Hias Tempel Keramik di Cirebon Jawa Barat. Jakarta: Pusat Penelitian Arkeologi Nasional.

Harkantiningsih, N. (2010). Aspek Arkeologi dalam Penelitian Keramik. Orasi Pengukuhan Profesor Riset Bidang Arkeologi. Jakarta: LIPI.

Jorg, C. J. A. (1984). Porselin Delft dan Keramik Negeri Belanda. In Interaksi Porselin Delft dan Keramik Timur. Jakarta: Museum Nasional.

Lapian, A. B. \& Sedyawati, E. (1996). Kajian Cirebon dan Kajian Jalur Sutra. In Zuhdi, S. (Ed.), Cirebon Sebagai Bandar Jalur Sutra. Kumpulan Makalah Diskusi Ilmiah (pp. 1-7). Jakarta: Departemen Pendidikan dan Kebudayaan Republik Indonesia.

Linasari, L. (1994). Ragam Hias Keraton Kasepuhan dan Kanoman di Cirebon. Skripsi, Universitas Indonesia.

Mulyawati, A. (1983). Keramik di Situs Astana Gunung Jati Cirebon. Skripsi, Universitas Indonesia.

NN. (1993). Azulejos de Portugal Seculos XVII e XVIII Rota da Asia: Ministerio Dos Negocios Estrangeiros de Portugal. Lisbon: Secretaria de Estado da Cultura de Portugal, Camara Municipal de Lisboa.

NN. (2014). TPKA (Tim Peningkatan Kinerja Arkeologi). Jakarta: Pusat Arkeologi Nasional, Kementerian Pendidikan dan kebudayaan.

Paramatatya, N. \& Ongkodharma, H. U. (2013). Corak Ragam Hias Keramik Tempel di Keraton Kasepuhan dan Kanoman di Cirebon. Depok: Universitas Indonesia. Retrieved July 4, 2017, from http/wwwlib.ui.ac.id/naskahringkas/201508/S44047-Nalada\%20Paramatatya

Sulistyono, S. T. (1996). Dari Lemahwungkuk hingga Chirebon: Pasang-surut Perkembangan Kora Cirebon sampai awal abad XX. In Zuhdi, S. (Ed.), Cirebon Sebagai Bandar Jalur Sutra. Kumpulan Makalah Diskusi Ilmiah (pp. 113-151). Jakarta: Departemen Pendidikan dan Kebudayaan Republik Indonesia. 
Tim Penelitian. (1985) Persebaran Situs-situs Masa Islam di Jawa Tengah Bagian Selatan. Berita Penelitian Arkeologi 35. Jakarta: Puslit Arkenas.

Tim Penelitian. (2003). Laporan Penelitian: Tata Kota Kuno di Wilayah Kesultanan Cirebon. Jakarta: Asdep Urusan Arkeologi Nasional.

Tjandrasasmita, U. (1996). Bandar Cirebon dalam Jaringan Pasar Dunia. In Zuhdi, S. (Ed.), Cirebon Sebagai Bandar Jalur Sutra. Kumpulan Makalah Diskusi Ilmiah (199-219). Jakarta: Departemen Pendidikan dan Kebudayaan Republik Indonesia. Undang-undang RI. Tentang Cagar Budaya, Pub. L. No. 11 (2010). 